\title{
Anti-metastatic and Anticancer Potentials of Synthesized Chalcones in B16-F10 Melanoma Cells Induced Metastatic Lung Cancer in C57BL/6 Mice
}

\author{
Nitesh Kumar ${ }^{1,2 \$}$, Nunsavath Kishan ${ }^{1 \$}$, Subhankar Biswas ${ }^{1}$, Karthik Gourishetti ${ }^{1}$, Mehnaz Kamal $^{3}$, \\ Mallikarjuna Rao Chamallamudi ${ }^{1, *}$ \\ ${ }^{1}$ Department of Pharmacology, Manipal College of Pharmaceutical Sciences, Manipal Academy of Higher Education, Manipal, \\ Karnataka, INDIA. \\ ${ }^{2}$ Department of Pharmacology and Toxicology, National Institute of Pharmaceutical Education and Research, Hajipur, Bihar, INDIA. \\ ${ }^{3}$ Department of Pharmaceutical Chemistry, College of Pharmacy, Prince Sattam bin Abdulaziz University, Al-Kharj -11942, \\ KINGDOM OF SAUDI ARABIA. \\ ${ }^{\$}$ Both the authors equally contributed
}

\begin{abstract}
Aim/Background: Metastasis is the main reason of death in cancer with a key challenge to target it precisely by the available treatments. The current study was designed to assess the anti-metastatic potentials of the synthesized chalcones, Ch-1 and Ch-2. Materials and Methods: In vitro study included cytotoxicity, scratch wound assay and cell cycle analysis of $\mathrm{Ch}-1$ and $\mathrm{Ch}-2$. In vivo study was performed in C57BL/6 mice in a B16-F10 induced metastatic lung cancer model. Results: Ch-1 was found to be a potent cytotoxic agent on cell lines namely, MCF-7 (human breast cancer cells), B16-F10 (melanoma cells), Hela (cervical cancer cells) and HEK (human embryonic kidney cells) with $\mathrm{IC}_{50}<100 \mu \mathrm{M}$. Ch- 1 deterred the $\mathrm{G}_{2} / \mathrm{M}$ phase of the MCF-7 cell cycle, S Phase of the HeLa cell cycle and $G_{0}-G_{1}$ phase of the B16-F10 cell cycle. Scratch wound assay in MCF-7 cells with Ch- 1 and Ch-2 showed a significant $(p<0.05)$ prevention in their multiplication when compared to untreated cells at both $24 \mathrm{~h}$ and $48 \mathrm{~h}$ intervals. In vivo study showed that, oral $\mathrm{Ch}-1$ administration at $100 \mathrm{mg} / \mathrm{kg} \mathrm{b} . \mathrm{w}$. reduced metastatic lung nodules to $77.32 \%$. Standard drug Quercetin at $100 \mathrm{mg} / \mathrm{kg} \mathrm{b.w}$. inhibited the lung tumor nodule formation to $56.5 \%$. However, except for WBC count, Ch-1 $(100 \mathrm{mg} / \mathrm{kg})$ also displayed significant improvement in hematological profile. No significant difference was found in any of the groups of animals in mean body weight and major organ weight. Conclusion: Study supports the possible use of $\mathrm{Ch}-1$ as a potential anticancer agent in metastatic lung cancer.
\end{abstract}

Key words: Chalcones, Anticancer, B16-F10 melanoma cells, Metastatic lung cancer, Cell Cycle.

\section{INTRODUCTION}

Cancer is an illness exemplified by the uncontrolled proliferation of aberrant cells that invade other tissues. ${ }^{1,2}$ It is the second most common reason for people's death after cardiovascular diseases. By the year 2020, the cancer cases in India are expected to increase up to $1,148,758$ cases from 979,786 cases in the year $2010 .^{3}$ From them, the most frequently stated cancer cases in India are lung, breast, colon, rectum and liver. The crucial cause of extreme mortality of anomalous cells is attributable to its invasive properties, which typically leads to metastasis. ${ }^{4}$ Metastasis occurs by the migration of tumor cells through the bloodstream and lymphatic system to other parts of the body.

In vivo, tumor cell metastasis to various organs is developed using B16-F10 melanoma cells that metastasize to the lungs and form malignant nodules. It is commonly employed in evaluating the effect
Submission Date: 12-02-2021; Revision Date: 10-04-2021; Accepted Date: 08-08-2021

DOI: 10.5530/ijper.55.3s.181 Correspondence: Dr. Mallikarjuna Rao Chamallamudi, Principal and Professor of Pharmacology, Manipal College of Pharmaceutical Sciences, Manipal Academy of Higher Education,

Manipal-576104, Karnataka, INDIA.

Phone: +91 820-2922482, Email - mallikin123@gmail. com

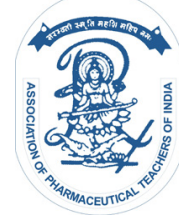

www.ijper.org 
of compounds for their anti-metastatic properties. Melanoma has distinct tumor tissue characteristics apropos prognosticative phases of cell proliferation, development, invasion and metastasis. B16-F10 melanoma cells are characterized by large tumor nodules and extreme metastatic ability. Its tumor microenvironment is potentially hypoxic that is accountable for its genetic instability. ${ }^{5,6}$ Injection site and tumor cell property predominantly define site location for metastasis. In rodents, the conventional injection sites of the cells are lateral tail vein, portal vein and intracardiac injection. Lateral tail vein injection directly targets lungs depicting metastasis. Portal vein injection targets liver and intracardiac injection predominantly target major organs including bone. The explanation of why tumor cells are injected laterally in the tail vein to produce metastatic lung cancer is because the cells will be directly exposed to blood for nutrients and growth factors and for immediate access to oxygen. ${ }^{7}$

Chalcones (1,3-diaryl-2-propen-1-ones) are a significant class of compounds from the flavonoid family, ${ }^{8}$ showing promising biological activities such as anticancer, antitumor, antioxidant, anti-inflammatory, antimalarial, antimicrobial, cytotoxic, anti-hepatotoxic, anti-allergic and analgesic and antipyretic activities. ${ }^{9}$ Chemically, they are made up of open-chain flavonoids where a three-carbon unsaturated carbonyl system joins the two aromatic rings. Chalcones are known to be a naturally occurring component with fewer side effects including genotoxicity similar to other anticancer drugs. ${ }^{10}$ Numerous chalcones were synthesized that exhibited potent toxicity against human cancer cell lines namely MCF-7 and HCT-116 with established molecular mechanisms with respect to the occurrence of apoptosis and cell cycle arrest. ${ }^{10}$ Nonetheless, there is relatively insufficient data on 2-hydroxy chalcones are an antitumor agent.

Therefore, we aimed to study the anti-metastatic and anticancer potentials of the synthesized chalcones, Ch-1 and Ch-2 in vitro using Sulforhodamine B (SRB) assay, cell cycle analysis, and scratch wound assay methods and in vivo anti-metastatic activity in $\mathrm{C} 57 \mathrm{BL} / 6$ mice having B16-F10 melanoma cells-induced lung metastasis.

\section{MATERIALS AND METHODS}

\section{Chemicals and reagents}

Standard drug Quercetin and chemicals used to synthesize chalcones Ch-1 and Ch- 2 were procured from SigmaAldrich Co. LLC, MO, USA.

\section{In vitro Studies}

Ch-1 and Ch-2 were screened in three cancer cell lines (MCF-7, HeLa and B16-F10 cells) and one normal cell line (HEK-Human embryonic kidney cells) for cytotoxicity analysis after $48 \mathrm{hr}$ of cell line exposure, using Sulforhodamine B (SRB) assay. The active Ch-1 molecule was subsequently chosen for the cell-cycle analysis studies on all three cancer cell lines. After $24 \mathrm{~h}$ and $48 \mathrm{~h}$ of their incubation with MCF-7 cells, scratch wound assay was done on MCF-7 cell lines to assess the anti-migratory potentials of Ch-1 and Ch-2.

\section{Cell lines and their maintenance}

Cells were acquired from the National Centre for Cell Science, Pune, India and maintained in complete media made with Dulbecco's Modified Eagle’s Medium (DMEM) (Sigma Aldrich Co., USA) and 10\% Fetal Bovine Serum (FBS) (HiMedia Laboratories, Mumbai, India) including antibiotic mixture $(1 \times$ Penicillin/ Streptomycin). The temperature was $37^{\circ} \mathrm{C}$ in a $\mathrm{CO}_{2}$ incubator (NU-5501 E/G, NuAire Inc., USA) with a humidified environment of $5 \% \mathrm{CO}_{2}$ and $95 \%$ air. Routine subculturing was done in tissue culture flasks of $25 \mathrm{~cm}^{2} .11,12$

\section{Cytotoxicity study by using the SRB assay}

Sulforhodamine B is an anionic dye, which binds to cellular proteins electrostatically. Its ability to bind to the protein components of cells is fastened by trichloroacetic acid (TCA) that secures the cells to the tissue culture plates. The cells growing in the log phase are seeded in tissue culture treated 96-well microplates $\left(10^{4}\right.$ cells / well in $100 \mu \mathrm{l}$ of medium) and kept in the $\mathrm{CO}_{2}$ incubator for $24 \mathrm{hr}$ at $37^{\circ} \mathrm{C}$. The cells have been exposed to varying compound concentrations from 10 to $200 \mu \mathrm{M}$. Ice-cold $30 \%$ TCA $(50 \mu \mathrm{l})$ was added to each well after $48 \mathrm{hr}$ of treatment for fixing of cells. The plate was incubated at $4^{\circ} \mathrm{C}$ for $1 \mathrm{hr}$, after which, the wells were rinsed with distilled water to ensure complete removal of TCA. Subsequently, $50 \mu \mathrm{l}$ of $0.05 \% \mathrm{w} / \mathrm{v}$ SRB dye prepared in 1\% acetic acid solution was added to the wells and incubated for $30 \mathrm{~min}$ under dark conditions. After incubation, the wells were washed with $1 \%$ acetic acid to eliminate any traces of unbound SRB and air-dried. Further, a $10 \mathrm{mM}$ Tris base was added to each well and allowed to dissolve the protein-bound dye. Absorbance was obtained using ELISA multi-well plate reader at $540 \mathrm{~nm} .^{13}$

The values of $\mathrm{IC}_{50}$ were determined by linear regression from the dose-response plots. 


\section{Cell cycle analysis}

Cells that grew exponentially were trypsinized from T-25 cell culture flasks and seeded in the sterile Petri plate. The cells were observed for attachment for about $24 \mathrm{~h}$, after which various treatments were introduced and the plates were further incubated for $48 \mathrm{~h}$. After $48 \mathrm{~h}$, the medium was aspirated and the plates were washed twice with phosphate buffer saline. Thereafter, the cells were trypsinized and centrifuged at $4{ }^{\circ} \mathrm{C}$, The pellet formed is resuspended in Dulbecco's PBS for fixation. Further, the cells were centrifuged, the supernatant was aspirated and the pellet was resuspended in RNAse-containing propidium iodide staining solution and NP-40 and incubated for 20 mins in the dark at room temperature. The cells were analyzed by $\mathrm{BD}$ Accuri ${ }^{\mathrm{TM}}$ C6 flow cytometer (BD Biosciences, San Jose, CA, USA). After centrifugation, the pellet was fixed in $70 \%$ ice-cold ethanol for $3 \mathrm{~h}$ at $4^{\circ} \mathrm{C} .{ }^{14}$

\section{Scratch wound assay}

Scratch wound assay was performed in MCF-7, human metastatic breast cancer cells to assess the ability of Ch-1 and Ch-2 to inhibit cell migration and antiproliferative ability. The cells were grown and maintained in DMEM supplemented by $10 \%$ FBS. At $70-80 \%$ confluency, the cells were seeded in 6-well plates (tissueculture treated) and allowed to form a monolayer. The cell monolayer formed was then slowly scratched with an autoclaved $200 \mu$ l pipette tip and the monolayer was rinsed with 1X PBS. Further, the wells were refilled with fresh medium. The distance of the scratch was evaluated before and after the addition of treatments at 24 and $48 \mathrm{~h}$ and photos of the same were taken. The distance was obtained quantitatively using image J software. ${ }^{15}$

\section{In vivo studies}

\section{Animals}

C57BL/6 mice were originally procured from the National Institute of Nutrition, Hyderabad and were bred at the Central Animal Research Facility, Manipal. The guidelines of Institutional Animal Ethics Committee guidelines, Manipal were followed for the animal care and experimentation. Upon receiving protocol approval (IAEC/KMC/16/2015) the mice were procured and acclimatized to experimental room conditions with temperature of $24 \pm 2^{\circ} \mathrm{C}$, humidity $(50 \pm 4 \%)$ and $12 \mathrm{~h}$ dark: light periods.

B16-F10 melanoma cells induced lung metastasis in C57BL/6 mice

C57BL/ 6 male mice weighing 20-25 g, aged 5 to 6 weeks, were arbitrarily grouped into four $(n=6) \mathrm{vir}$. normal control group (0.25\% CMC, $10 \mathrm{ml} / \mathrm{kg}$, p.o.), B16-F10 control group (0.25\% CMC, $10 \mathrm{ml} / \mathrm{kg}$, p.o.), Quercetin (HDAC standard) group (100 mg/kg, p.o.) and Ch-1 treatment group $(100 \mathrm{mg} / \mathrm{kg}$, p.o.).

Induction of lung cancer was attained using B16-F10 melanoma cells according to an earlier described method. ${ }^{12}$ B16-F10 cells were washed, trypsinized, and resuspended in serum-free DMEM medium. About $0.5 \times 10^{6}$ cells $/ 100 \mu \mathrm{l}$ were steadily injected on day zero into the lateral tail vein with precautions to reduce the development of emboli. Treatment was started from day 1 daily upto 14 days. Bodyweight was measured on the $15^{\text {th }}$ day, then the animals were euthanized and hematological parameters assessed.

Major organs such as the heart, lungs, kidneys, liver and spleen were isolated and fixed with Bouin's solution. The lungs were photographed and counted on the entire lung surface for the metastatic lung nodules/ colonies visible to the naked eye. ${ }^{16}$

\section{Organ index}

The organs were isolated and weighed in grams, namely, liver, kidney, heart and spleen. The organ index was calculated using the formula below: $:^{15}$

$$
\begin{gathered}
\text { Organ index }=\text { Organ weight (in g)/ Body weight of } \\
\text { the animal (in g) }
\end{gathered}
$$

\section{Hematological parameters}

WBC count, RBC count, Hemoglobin count and Platelet count were checked in lung cancer-bearing mice to detect the effect of chalcones using ERMA veterinary blood cell counter, Japan. ${ }^{17}$

\section{Statistical analysis}

The analysis was performed by one-way ANOVA followed by Tukey's posthoc test and Two-way ANOVA followed by Bonferroni posthoc test using GraphPad Prism 7 Version (evaluation) with a $p<0.05$ was considered significant.

\section{RESULTS}

\section{Synthesis of compounds Ch-1 and Ch-2}

Chalcone derivatives, 1-(2,4-dihydroxy-phenyl)3-(4-dimethylamino-phenyl)-propenone (Ch-1) and 1-(2-hydroxy-4-methyl-phenyl)-3-p-toli-propenone (Ch2) were synthesized according to the reported procedure (Pande et al. 2017). Synthesized compounds produced were characterized by mass spectrometry, ${ }^{1} \mathrm{H}$ NMR and FTIR. Chemical structures of the synthesized compounds Ch-1 and Ch-2 were shown in Figure 1. 


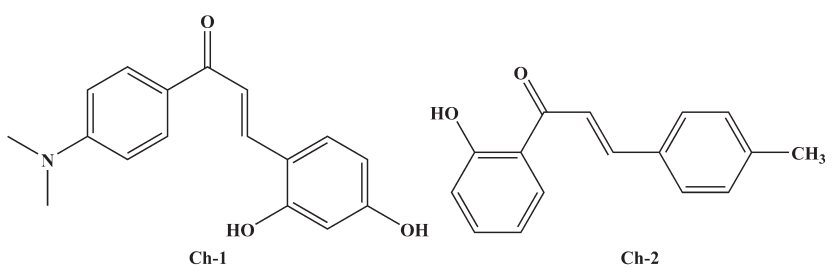

Figure 1: Chemical structures of the synthesized compounds Ch-1 and Ch-2.

\begin{tabular}{|c|c|c|c|c|}
\hline Compound & $\begin{array}{c}\text { MCF-7 } \\
\left(\mathrm{IC}_{50} \text { in }\right. \\
\mu \mathrm{M})\end{array}$ & $\begin{array}{c}\text { B16-F10 } \\
\left(\mathrm{IC}_{50} \text { in }\right. \\
\mu \mathrm{M})\end{array}$ & $\begin{array}{c}\text { HeLa } \\
\left(\mathrm{IC}_{50} \text { in }\right. \\
\mu \mathrm{M})\end{array}$ & $\begin{array}{c}\text { HEK } \\
\left(\begin{array}{l}\text { IC }_{50} \text { in } \\
\mu M)\end{array}\right.\end{array}$ \\
\hline Ch-1 & 27.55 & 42.35 & 60 & 59.11 \\
\hline Ch-2 & 192.9 & 220.5 & 382.2 & 300.5 \\
\hline 5-FU & 15.43 & 20.35 & 10.75 & 4.806 \\
\hline
\end{tabular}

\section{In vitro studies}

\section{Cytotoxicity assay by using the SRB assay}

In vitro cytotoxicity effect of Ch-1 and Ch-2 in MCF-7 (human breast cancer cell line), Hela cell line (cervical cancer cell line) and HEK cell line by Sulforhodamine $\mathrm{B}$ after $48 \mathrm{~h}$ of contact showed that the synthesized compounds showed a dose-dependent reduction in the $\%$ viability of the cells. $\mathrm{IC}_{50}$ values for $\mathrm{Ch}-1$ and $\mathrm{Ch}-2$ were found to be $27.55 \mu \mathrm{M}$ and $192.9 \mu \mathrm{M}$, respectively in the MCF-7 cell line, $42.35 \mu \mathrm{M}$ and $220.5 \mu \mathrm{M}$, respectively in B16-F10 cell line, $60 \mu \mathrm{M}$ and $382.2 \mu \mathrm{M}$, respectively in HeLa cell line and $59.11 \mu \mathrm{M}$ and 300.5 $\mu \mathrm{M}$, respectively in HEK cell line (Table 1).

\section{Cell cycle analysis}

Cell Cycle analysis on MCF-7 cell line: Cell cycle analysis was conducted to establish which phase of the cell cycle in the MCF-7 cell line is being arrested by Ch-1 and it was observed that Ch-1 arrested the cell cycle's $\mathrm{G}_{2} / \mathrm{M}$ stage (Figure 2).

Cell cycle analysis on HeLa cell line: Cell cycle analysis was conducted to verify which phase of the cell cycle in the HeLa cell line is being arrested by Ch-1 and it was observed that at a concentration of $80 \mu \mathrm{M}$, it arrested the cell cycle's $S$ stage (Figure 3 ).

Cell cycle analysis on B16-F10 cell line: Analysis of the cell cycle was carried out to determine which phase of the cell cycle in the B16-F10 cell line is being arrested by $\mathrm{Ch}-1$ and it was observed that it arrested the cell cycle's $\mathrm{G}_{0}-\mathrm{G}_{1}$ stage (Figure 4).

\section{Scratch wound assay}

Doxorubicin, Ch-1, and Ch-2 significantly $(p<0.05)$ inhibited cell proliferation at both points of time
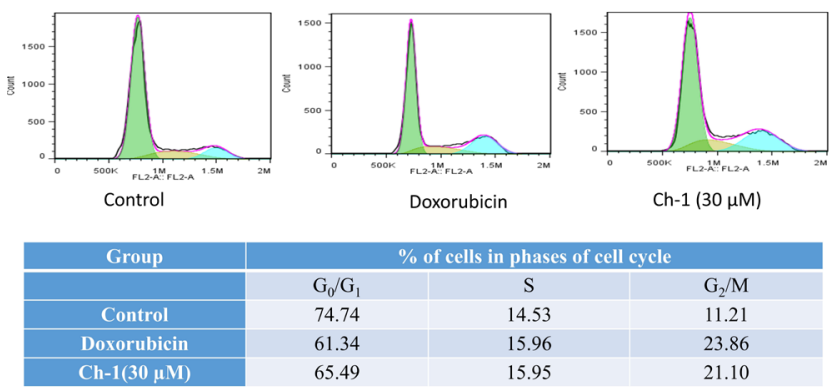

Figure 2: Effect of Ch-1 and Doxorubicin on MCF-7 cell cycle.
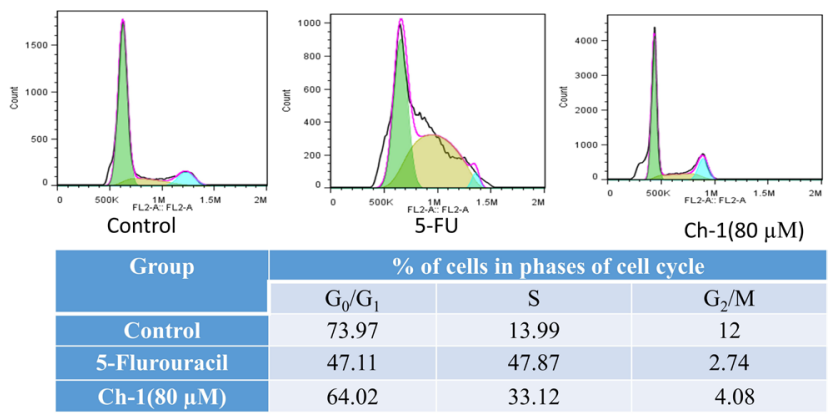

Figure 3: Effect of Ch-1 and Doxorubicin on the HeLa cell cycle.
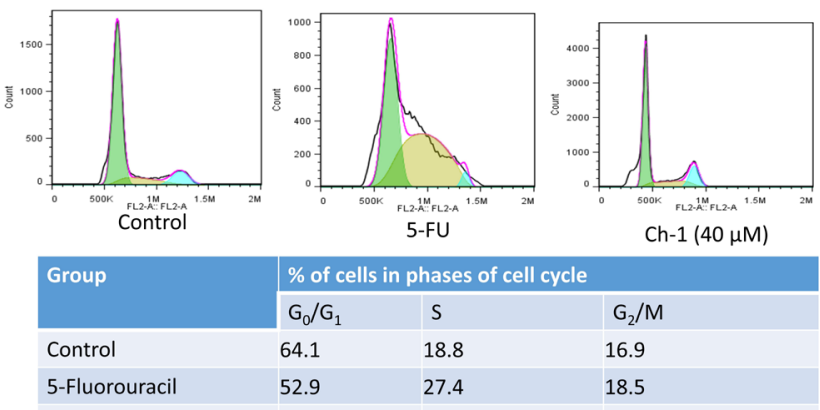

$\%$ of cells in phases of cell cycle

$\begin{array}{ccc}\mathrm{G}_{0} / \mathrm{G}_{1} & \mathrm{~S} & \mathrm{G}_{2} / \mathrm{M} \\ 64.1 & 18.8 & 16.9 \\ 52.9 & 27.4 & 18.5 \\ 67.2 & 16.8 & 15.4\end{array}$

Figure 4: Effect of Ch-1 and Doxorubicin on B16-F10 cell cycle.

(24 h and $48 \mathrm{~h}$ ) compared to control cells. No significant differences among Doxorubicin, Ch-1 and Ch-2 were found (Table 2).

\section{In vivo studies}

\section{Body weight profile}

No significant changes in mean body weight were found in any of the animal groups (Figure 5).

\section{Lung tumor nodule count and lung index}

The numbers of metastatic lung tumor nodules in B16-F10 control group, Quercetin $(100 \mathrm{mg} / \mathrm{kg})$ group and Ch-1 group $(100 \mathrm{mg} / \mathrm{kg})$ animals were found to 


\begin{tabular}{|c|c|c|c|}
\hline \multirow{4}{*}{ Treatment } & \multicolumn{3}{|c|}{ Wound width $(\boldsymbol{\mu M})$} \\
\cline { 2 - 4 } & $\mathbf{0 ~} \mathbf{h}$ & $\mathbf{2 4} \mathbf{~}$ & $\mathbf{4 8} \mathbf{~ h}$ \\
\hline Control & $520 \pm 11$ & $250 \pm 9$ & $150 \pm 5$ \\
\hline Doxorubicin & $490 \pm 6$ & $521 \pm 14^{*}$ & $500 \pm 15^{*}$ \\
\hline Ch-1 & $506 \pm 18$ & $530 \pm 20^{*}$ & $560 \pm 10^{*}$ \\
\hline Ch-2 & $500 \pm 9$ & $490 \pm 16^{*}$ & $386 \pm 20^{*}$ \\
\hline
\end{tabular}

Effect of Ch-1 and Ch-2 $(100 \mathrm{mg} / \mathrm{ml})$ treatment on scratch wound created in the monolayer of MCF- 7 cells at $24 \mathrm{~h}$ and $48 \mathrm{~h}$ time intervals. All the values were expressed as mean \pm SEM and analysed by Two-way ANOVA followed by Bonferroni posthoc test method using Graph Pad Prism, where * $p<0.05$ compared to control.

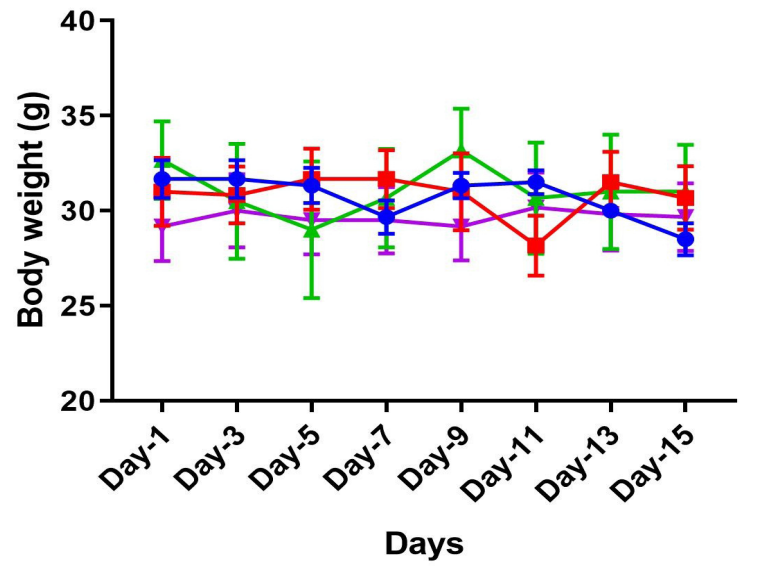

$$
\begin{aligned}
& \rightarrow \text { Control } \rightarrow \text { B16-F10 control }(100 \mathrm{mg} / \mathrm{kg}) \\
& \leftarrow \text { Quercetin }(100 \mathrm{mg} / \mathrm{kg}) \rightarrow \text { Ch-1 }(100 \mathrm{mg} / \mathrm{kg})
\end{aligned}
$$

Figure 5: Effect of 14-day treatment on changes in the body weight in B16-F10 mediated lung metastasis.

Body weight of normal control, B16-F10 control, Quercetin $(100 \mathrm{mg} / \mathrm{kg})$ and $\mathrm{Ch}-1$ $(100 \mathrm{mg} / \mathrm{kg})$ groups were noted on the odd number of days starting day-1 to the day15 of treatment schedule. Values were expressed as mean \pm SEM. Statistical analysis was performed by two-way ANOVA followed by Bonferroni posthoc test, where $p$ $<0.05$ considered significant compared to the normal control group and B16-F10 control.
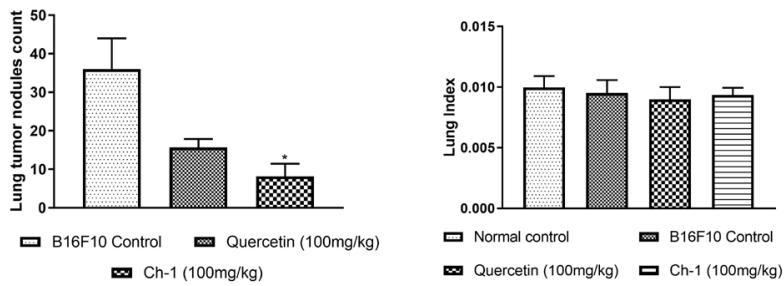

Figure 6: Effect of $\mathrm{Ch}-1$ on lung tumor nodule count and lung index.

be $36,15.66$ and 8.166 , respectively which showed $\%$ inhibition of lung tumor nodule formation is $56.5 \%$ in Quercetin group and $77.32 \%$ in Ch-1 group, respectively (Figure 6, Table 3).

\section{Table 3: Effect of Ch-1 and Quercetin in the inhibition} of lung tumor nodule formation.

\begin{tabular}{|c|c|c|c|}
\hline $\begin{array}{c}\text { S. } \\
\text { No. }\end{array}$ & Group & $\begin{array}{c}\text { Number of } \\
\text { metastatic lung } \\
\text { tumor nodules }\end{array}$ & $\begin{array}{c}\% \text { inhibition } \\
\text { of lung } \\
\text { tumor nodule } \\
\text { formation }\end{array}$ \\
\hline 1 & Normal control & 0 & 0 \\
\hline 2 & B16-F10 control & $36 \pm 7.98$ & 56.5 \\
\hline 3 & $\begin{array}{c}\text { Quercetin } \\
(100 \mathrm{mg} / \mathrm{kg})\end{array}$ & $15.66 \pm 2.20$ & $77.32^{*}$ \\
\hline 4 & Ch-1 $(100 \mathrm{mg} / \mathrm{kg})$ & $8.166 \pm 3.28$ & \\
\hline
\end{tabular}

All values were represented as mean \pm SEM. ${ }^{*} p<0.05$ compared to Ch-1.

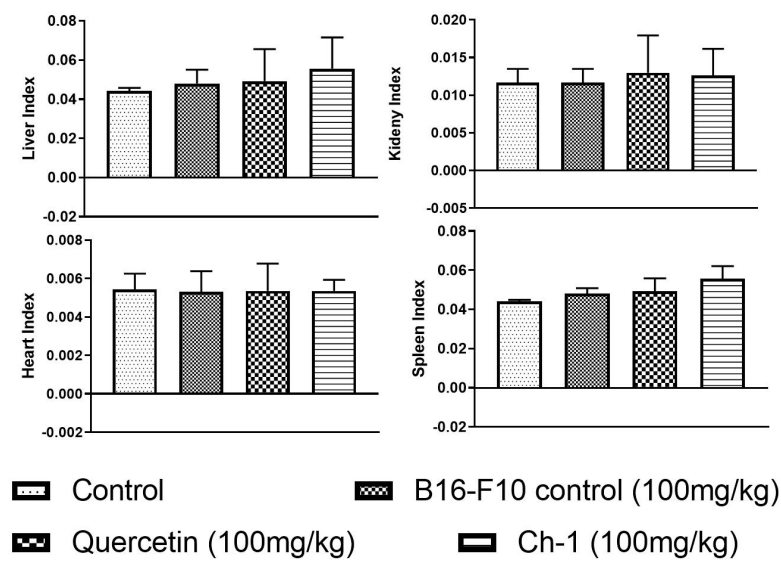

Figure 7: Effect of Ch-1 (100 mg/kg, p.o.) and Quercetin (100 mg/kg, p.o.) treatment on organ index in C57BL/6 mice.

(a) Liver index (b) Kidney index (c) Heart index (d) Spleen index. All values were expressed as mean \pm SEM and analysed by one-way ANOVA followed by the Tukey posthoc test

\section{Organ index}

No significant changes in major organ weight were found in any of the animal groups (Figure 7).

\section{Hematological parameters}

A significant reduction in RBC, WBC, hemoglobin count and platelet count was found in B16-F10 positive control animals. Treatment with quercetin $(100 \mathrm{mg} / \mathrm{kg})$ significantly restored improvements in hematological parameters as compared to B16-F10 control. Ch-1 (100 $\mathrm{mg} / \mathrm{kg}$ ) has also shown significant improvements in hematological parameters with the exception of WBC count (Figure 8).

\section{DISCUSSION}

In the current investigation, the chalcone derivatives Ch-1 and Ch-2 were synthesized and their in vitro and in vivo anticancer and anti-metastatic potentials were evaluated. The cytotoxicity potential of the synthesized 

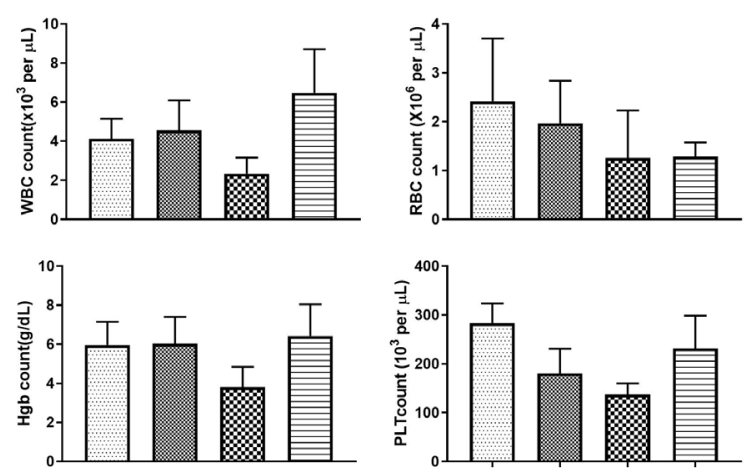

$\square$ Normal control B16-F10 control Standard $\square$ Ch-1 (100mg/kg)

Figure 8: Effect of Ch-1 (100 mg/kg, p.o.) and Quercetin $(100 \mathrm{mg} / \mathrm{kg}$, p.o.) treatment on the blood cells count in C57BL/6 mice.

All values were expressed as mean \pm SEM and analysed by one-way ANOVA followed by the Tukey posthoc test.

chalcones, Ch-1 and Ch-2 were evaluated by performing SRB assay in MCF-7 (human breast cancer cell line), Hela cell line (cervical cancer cell line) and HEK cell line with an incubation period of $48 \mathrm{~h}$. The Ch-1 was found to have good cytotoxicity potential with $\mathrm{IC}_{50}$ values below $100 \mu \mathrm{M}$ against MCF-7, B16-F10, HeLa and HEK cancer cell lines.

One of the critical studies is the study of the cell cycle analysis, to evaluate the specific cytotoxic effects. The anticancer compounds prevent the cell cycle by activating checkpoint or by inhibiting the progression of the cell cycle either in $G_{0} / G_{1}, S$ Phase or $G_{2} / M$ phase. In the present study, along with the cytotoxic effect, the effect of Ch-1 and Ch- 2 was also studied on the cell cycle of the tested cell lines. In the MCF-7 cell line, 74.74\% of the cells were in the $G_{0} / G_{1}$ phase, $14.53 \%$ of the cells were in the $S$ phase and $11.21 \%$ of the cells were in the $\mathrm{G}_{2} / \mathrm{M}$ phase in the control group. However, treatment with Doxorubicin showed an escalation in the percentage of cell number in the $\mathrm{G}_{2} / \mathrm{M}$ phase $(23.86 \%)$ compared to the control group which suggests that it is a $G_{2} / M$ phase blocker. Moreover, an increase in the $\%$ of cells in the $G_{2} / M$ phase of the cell cycle was observed at $30 \mu \mathrm{M}$ with Ch-1 treatment, with $21.10 \%$. In the HeLa cell line, $73.97 \%$ of the cells were in the $G_{0} / G_{1}$ phase, $13.99 \%$ of the cells were in the $S$ phase and $12 \%$ of the cells were in the $G_{2} / M$ phase in the control group. However, treatment with 5-Fluorouracil reported a percentage increase in cells in the $S$ phase $(47.87 \%)$ compared to the control group which suggests that it is an $S$ phase blocker. Moreover, a percentage increase in cells in the $S$ phase of the cell cycle was observed with Ch- 1 treatment at $80 \mu \mathrm{M}$ and the percentage was 33.12.
In the B16-F10 cell line, $64.1 \%$ of the cells were in the $\mathrm{G}_{0} / \mathrm{G}_{1}$ phase, $18.8 \%$ of the cells were in the $S$ phase and $16.9 \%$ of the cells were in the $\mathrm{G}_{2} / \mathrm{M}$ phase in the control group. However, treatment with 5-Fluorouracil showed an increase in the percentage of $S$ phase cells $(27.4 \%)$ compared to the control group which suggests that it is an $S$ phase blocker. Moreover, elevation in the percentage of cell number in the cell cycle $G_{0}-G_{1}$ phase was witnessed at $40 \mu \mathrm{M}$ with $\mathrm{Ch}-1$ treatment and the percentage was 67.2.

Metastasis is the stage of cancer in which the tumor cells break away from the site of origin to different parts of the body, which makes the cancer therapy very difficult to control cancer advancement. The in vitro study scratch wound assay is an important method to assess metastasis as well as cell proliferation. In this study the scratch is made in cells and proliferation is observed for various time intervals. ${ }^{18}$ To evaluate the potential of synthesized chalcones, Ch- 1 and Ch- 2 to inhibit migration and metastasis, percentages of cell migration after treatment with the standard drug and Ch-1 and Ch-2 were evaluated in MCF-7 cell lines. Doxorubicin was used as a standard drug at concentration $3 \mu \mathrm{M}$ and the untreated group as the positive control. Ch-1 significantly reduced cell migration at 24 and $48 \mathrm{hr}$ after treatment as compared to control. The treatments with these chalcones (Ch-1 and Ch-2) resulted in the inhibition of the motile behavior of cancer cells. In the earlier study also, Ch-1 and Ch-2 were reported to be more active candidates in both in vitro and in vivo models for the treatment of colon carcinoma. ${ }^{19}$

In the B16-F10 lung metastasis mice model, reduced lung tumor nodules count and blood parameter recovery suggested the effectiveness of compounds to prevent metastasis. All of these tests revealed that Ch-1 was a beneficial anticancer and anti-metastatic agent with effectiveness equal to the established norm, which showed the safety of the tested compound on various organ systems. Organ index is a marker of toxicity which was calculated for kidney, liver, spleen and heart in all the groups. No significant difference was observed in the kidney, liver, spleen and heart index.

\section{CONCLUSION}

Ch-1 and Ch-2 were assessed for in vitro anticancer activities such as SRB assay, cell cycle analysis and scratch wound assay and in vivo anti-metastatic activity in B16-F10 melanoma cells induced lung metastasis in C57BL/6 mice to models such as evaluation of lung nodules and lung index, organ index and hematological 
parameters. In in vitro cytotoxicity studies, both compounds Ch-1 and Ch-2 produced a dose-dependent reduction in the percentage viability of the cells. Ch-1 arrested at different phases of the cell cycle in MCF-7, HeLa and B16-F10 cell cycle. Both the compounds significantly $(\phi<0.05)$ prevented cell proliferation of MCF-7 human metastatic breast cancer cells in comparison to negative control at 24 and $48 \mathrm{~h}$. Attenuation of tumor nodule count in the lungs and the improvement in the blood parameters in the B16-F10 lung metastasis mice model demonstrated their ability to preclude metastasis. All of the findings suggested that Ch- 1 is a potential anticancer and anti-metastatic agent with effectiveness comparable to the existing standards.

\section{ACKNOWLEDGEMENT}

We thank Manipal College of Pharmaceutical Sciences, Manipal Academy of Higher Education, Manipal, for providing infrastructural support.

\section{CONFLICT OF INTEREST}

The authors declare no conflict of interest.

\section{Ethical Approval}

Ethical approval obtained from the Institutional Animal Ethics Committee (IAEC) of KMC Manipal with the research proposal number IAEC/KMC/16/2015.

\section{ABBREVIATIONS}

Ch1: 1-(2,4-dihydroxy-phenyl)-3-(4-dimethylamino-phenyl)propenone; Ch-2: 1-(2-hydroxy-4-methyl-phenyl)3-p-toli-propenone; SRB: Sulforhodamine B assay; DMEM: Dulbecco's Modified Eagle's Medium; FBS: Fetal Bovine Serum; TCA: Trichloroacetic acid.

\section{REFERENCES}

1. Prabhu VV, Guruvayoorappan C. Inhibition of metastatic lung cancer in C57BL/6 mice by marine mangrove Rhizophora apiculata. Asian Pac J Cancer Prev. 2013;14(3):1833-40. doi: 10.7314/apjcp.2013.14.3.1833, PMID 23679283.

2. Jayashree BS, Nigam S, Pai A, Patel HK, Reddy ND, Kumar N, Rao CM. Targets in anticancer research--a review. Indian J Exp Biol. 2015;53(8):489-507. PMID 26349312.

3. Takiar R, Nadayil D, Nandakumar A. Projections of number of cancer cases in India (2010-2020) by cancer groups. Asian Pac J Cancer Prev. 2010;11(4):1045-9. PMID 21133622.
4. Khan N, Mukhtar H. Cancer and metastasis: prevention and treatment by green tea. Cancer Metastasis Rev. 2010;29(3):435-45. doi: 10.1007/s10555010-9236-1, PMID 20714789.

5. Fidler IJ. The pathogenesis of cancer metastasis: the 'seed and soil' hypothesis revisited. Nat Rev Cancer. 2003;3(6):453-8. doi: 10.1038/ nrc1098, PMID 12778135.

6. Fidler IJ. Selection of successive tumour lines for metastasis. Nat New Biol. 1973;242(118):148-9. doi: 10.1038/newbio242148a0, PMID 4512654.

7. Khanna C, Hunter K. Modeling metastasis in vivo. Carcinogenesis. 2005;26(3):513-23. doi: 10.1093/carcin/bgh261, PMID 15358632.

8. Chimenti F, Fioravanti R, Bolasco A, Chimenti P, Secci D, Rossi F, Yáñez M, Orallo F, Ortuso F, Alcaro S. Chalcones: A valid scaffold for monoamine oxidases inhibitors. J Med Chem. 2009;52(9):2818-24. doi: 10.1021/ jm801590u, PMID 19378991.

9. Simon L, Srinivasan KK, Kumar N, Reddy ND, Biswas S, Rao CM, Moorkoth S. Selected novel 5'-amino-2'-hydroxy-1, 3-diaryl-2-propen-1-ones arrest cell cycle of HCT-116 in G0/G1 phase. Excli J. 2016;15:21-32. doi: 10.17179/ excli2015-610, PMID 27152112.

10. Kumar SK, Hager E, Pettit C, Gurulingappa H, Davidson NE, Khan SR. Design, synthesis, and evaluation of novel boronic-chalcone derivatives as antitumor agents. J Med Chem. 2003;46(14):2813-5. doi: 10.1021/ jm030213+, PMID 12825923.

11. Menon LG, Kuttan R, Kuttan G. Inhibition of lung metastasis in mice induced by B16F10 melanoma cells by polyphenolic compounds. Cancer Lett. 1995;95(1-2):221-5. doi: 10.1016/0304-3835(95)03887-3, PMID 7656234.

12. Havanur S, Batish I, Cheruku SP, Gourishetti K, P E J, Kumar N. Poly(N,Ndiethyl acrylamide)/functionalized graphene quantum dots hydrogels loaded with doxorubicin as a nano-drug carrier for metastatic lung cancer in mice. Mater Sci Eng C Mater Biol Appl. 2019;105:110094. doi: 10.1016/j. msec.2019.110094.

13. Talwar S, Jagani HV, Nayak PG, Kumar N, Kishore A, Bansal P, Shenoy RR, Nandakumar K. Toxicological evaluation of Terminalia paniculata bark extract and its protective effect against $\mathrm{CCl} 4$-induced liver injury in rodents. BMC Complement Altern Med. 2013;13:127. doi: 10.1186/1472-6882-13-127, PMID 23742226.

14. Reddy ND, Shoja MH, Jayashree BS, Nayak PG, Kumar N, Prasad VG, Pai KS, Rao CM. In vitro and in vivo evaluation of novel cinnamyl sulfonamide hydroxamate derivative against colon adenocarcinoma. Chem Biol Interact. 2015;233:81-94. doi: 10.1016/j.cbi.2015.03.015, PMID 25824412.

15. Wankhede S, Kumar N, Simon L, Biswas S, Gourishetti K, Ramalingayya GV, Joshi M, Rao CM. Evaluation of in vitro and in vivo anticancer potential of two 5-acetamido chalcones against breast cancer. Excli J. 2017;16:1150-63. doi: 10.17179/excli2017-624, PMID 29285012.

16. Brown LM, Welch DR, Rannels SR. B16F10 melanoma cell colonization of mouse lung is enhanced by partial pneumonectomy. Clin Exp Metastasis. 2002;19(5):369-76. doi: 10.1023/a:1016345627965, PMID 12198764.

17. Kumar R, Kumar N, Ramalingayya GV, Setty MM, Pai KS. Evaluation of Ceiba pentandra (L.) Gaertner bark extracts for in vitro cytotoxicity on cancer cells and in vivo antitumor activity in solid and liquid tumor models. Cytotechnology. 2016;68(5):1909-23. doi: 10.1007/s10616-016-0002-2, PMID 27456242.

18. Reddy ND, Shoja MH, Biswas S, Nayak PG, Kumar N, Rao CM. An appraisal of cinnamyl sulfonamide hydroxamate derivatives (HDAC inhibitors) for anticancer, anti-angiogenic and anti-metastatic activities in human cancer cells. Chem Biol Interact. 2016;253:112-24. doi: 10.1016/j.cbi.2016.05.008, PMID 27163855.

19. Pande AN, Biswas S, Reddy ND, Jayashree BS, Kumar N, Rao CM. In vitro and in vivo anticancer studies of 2'-hydroxy chalcone derivatives exhibit apoptosis in colon cancer cells by HDAC inhibition and cell cycle arrest. Excli J. 2017;16:448-63. doi: 10.17179/excli2016-643, PMID 28694750 . 

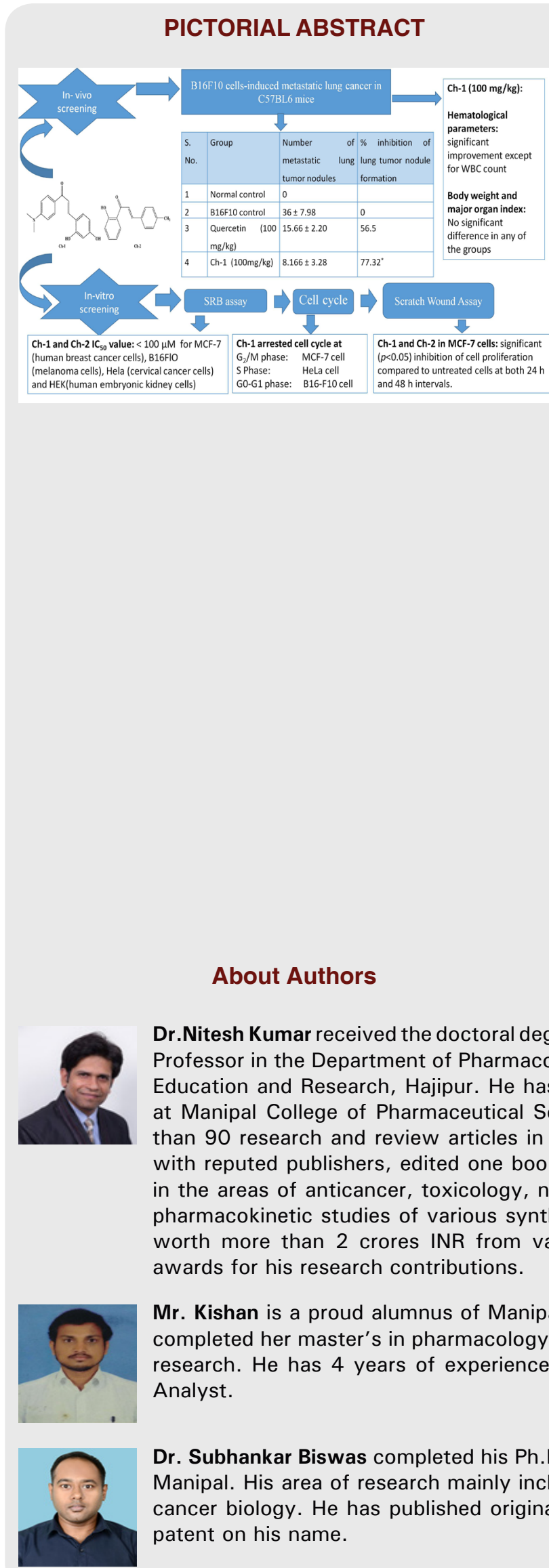

\section{About Authors}

Dr.Nitesh Kumar received the doctoral degree in the year 2013. Currently, he is working as an Assistant Professor in the Department of Pharmacology and Toxicology at National Institute of Pharmaceutical Education and Research, Hajipur. He has more than 10 years of teaching and research experience at Manipal College of Pharmaceutical Sciences, MAHE, Manipal. Till date, he has published more than 90 research and review articles in Indian and International reputed journals, 3 book chapters with reputed publishers, edited one book and applied for 3 patents. His research contributions are in the areas of anticancer, toxicology, neuropharmacology, nanoformulation, hepatoprotection and pharmacokinetic studies of various synthetic and natural products. He has received several grants worth more than 2 crores INR from various Industry and Government agencies and received 5 awards for his research contributions.

Mr. Kishan is a proud alumnus of Manipal College of Pharmaceutical Sciences, MAHE, Manipal. He completed her master's in pharmacology, in the year 2017. His research was focussed in anticancer research. He has 4 years of experience in Clinztech Research Solutions Pvt Ltd, as Clinical Data Analyst.

Dr. Subhankar Biswas completed his Ph.D from Manipal College of Pharmaceutical Sciences, MAHE, Manipal. His area of research mainly includes computer-aided drug design, synthetic chemistry and cancer biology. He has published original and review articles at peer-reviewed journals and hold a patent on his name. 


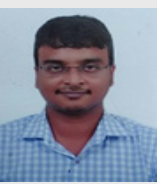

Dr. Karthik Gourishetti completed his PhD from Manipal College of Pharmaceutical Sciences, MAHE, Manipal. He is working at CSIR-Indian Institute of Chemical Technology, as a Research Associate. Dr. Karthik Gourishetti has extensively worked in the research areas like Diabetic wound healing, Chemo brain, NASH, Pulmonary fibrosis, Diabetes and has published plenty of his work in peerreviewed journals.

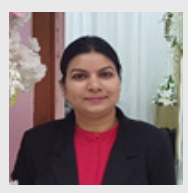

Dr. Mehnaz Kamal, Ph.D., is currently working as an Associate Professor in College of Pharmacy, Prince Sattam Bin Abdulaziz University, Al-Kharj, Saudi Arabia. She has more than 13 years of experience in research and teaching. She has to her credit more than 70 research and review articles in peer-reviewed national and international journals, 2 book chapters with Wiley publisher and hold an Indian patent on her name.

Dr. C. Mallikarjuna Rao completed his PhD in the year 1990. At present, he is leading the Manipal College of Pharmaceutical Sciences upfront as Principal since 2013. In total, he has more than 150 publications in national and international journals and has received 24 research funds. His area of research includes, wound healing, oncology, metabolic disorders and hepatotoxicity.

Cite this article: Kumar N, Kishan N, Biswas S, Gourishetti K, Kamal M, Chamallamudi MR. Anti-metastatic and Anticancer Potentials of Synthesized Chalcones in B16-F10 Melanoma Cells Induced Metastatic Lung Cancer in C57BL/6 Mice. Indian J of Pharmaceutical Education and Research. 2021;55(3s):s742-s750. 